Island Studies Journal, Vol. 11, No. 2, 2016, pp. 673-686

\title{
REVIEW ESSAY \\ Interdisciplinary island studies: connecting the social sciences, natural sciences and humanities
}

\author{
Sietze J. Norder \\ Institute for Interdisciplinary Studies; Institute for Biodiversity and Ecosystem Dynamics \\ University of Amsterdam, The Netherlands \\ \& \\ Centre for Ecology, Evolution and Environmental Changes; Azorean Biodiversity Group \\ Universidade de Lisboa, Portugal. \\ S.J.Norder@uva.nl
}

and

Kenneth F. Rijsdijk

Institute for Interdisciplinary Studies; Institute for Biodiversity and Ecosystem Dynamics University of Amsterdam, The Netherlands

K.F.Rijsdijk@uva.nl

\begin{abstract}
In this paper, we present the outline of an interdisciplinary undergraduate course entitled: "Islands: Models for our Planet - Metaphors for our World", and will reflect on insights gained during its development and teaching in two consecutive academic years (2014-2015; 2015-2016). The main challenge faced during the development and teaching of this interdisciplinary course was to introduce a wide range of topics in a coherent way. For this reason, a theoretical framework was developed to guide students throughout their learning process and to structure the content of the course. The developed course materials are shared in the supplementary materials of this paper to facilitate colleagues around the world who are teaching a course in island studies.
\end{abstract}

Keywords: course development, critical alignment, elective undergraduate course, island studies, open source teaching materials, social-ecological systems.

C 2016 - Institute of Island Studies, University of Prince Edward Island, Canada.

\section{Introduction}

International sharing of educational experiences is worthwhile for introductory courses at an undergraduate level since these courses are generally not very specialized. Especially for island studies courses, which are being thought in few universities around the world, it is sensible to share experiences. Aligning the introductory island studies courses that are being taught around the world might eventually facilitate international student exchange and equivalence recognition of courses. Two examples of island studies courses for which teaching experiences are shared are the elective undergraduate course "Introduction to Island Studies" which is part of the Island Studies Minor at the University of Prince Edward Island (Stuart, 2010) and the course "Islands \& Isolation" which is part of the first year liberal arts 
undergraduate program at Lafayette College (Sunderlin \& Xu, 2008). In this paper, we reflect on the development of the course "Islands: Models for our Planet: Metaphors for our World (IMPMW)" and its teaching in two consecutive academic years (2014-15, 2015-16). This elective introductory course to the field of island studies was offered by the Institute for Interdisciplinary Studies (IIS) at the University of Amsterdam (UvA) and was initiated and developed by the authors of this paper (also core teachers of the course). The IMPMW course was open to $2^{\text {nd }}$ and $3^{\text {rd }}$ year undergraduate students from all disciplines in the social sciences, natural sciences and humanities (Table 1).

Table 1: Characteristics of the course "Islands: Models for our Planet: Metaphors for our World (IMPMW)"

\begin{tabular}{|l|l|}
\hline Type of course & Elective \\
\hline Level & Undergraduate $\left(2^{\text {nd }}\right.$ and $3^{\text {rd }}$ year bachelor) \\
\hline Number of European Credits (EC) & 6 EC (equivalent to 168 hours) \\
\hline Course duration & 12 weeks \\
\hline Number of contact hours per week & 2 hours (evening classes) \\
\hline $\begin{array}{l}\text { Number of students taking part in } \\
\text { examination }\end{array}$ & $36-55$ \\
\hline
\end{tabular}

Figure 1: Logo of the course "Islands: Models for our Planet: Metaphors for our World" (left figure). The logo has the contours of Pangea (right figure).
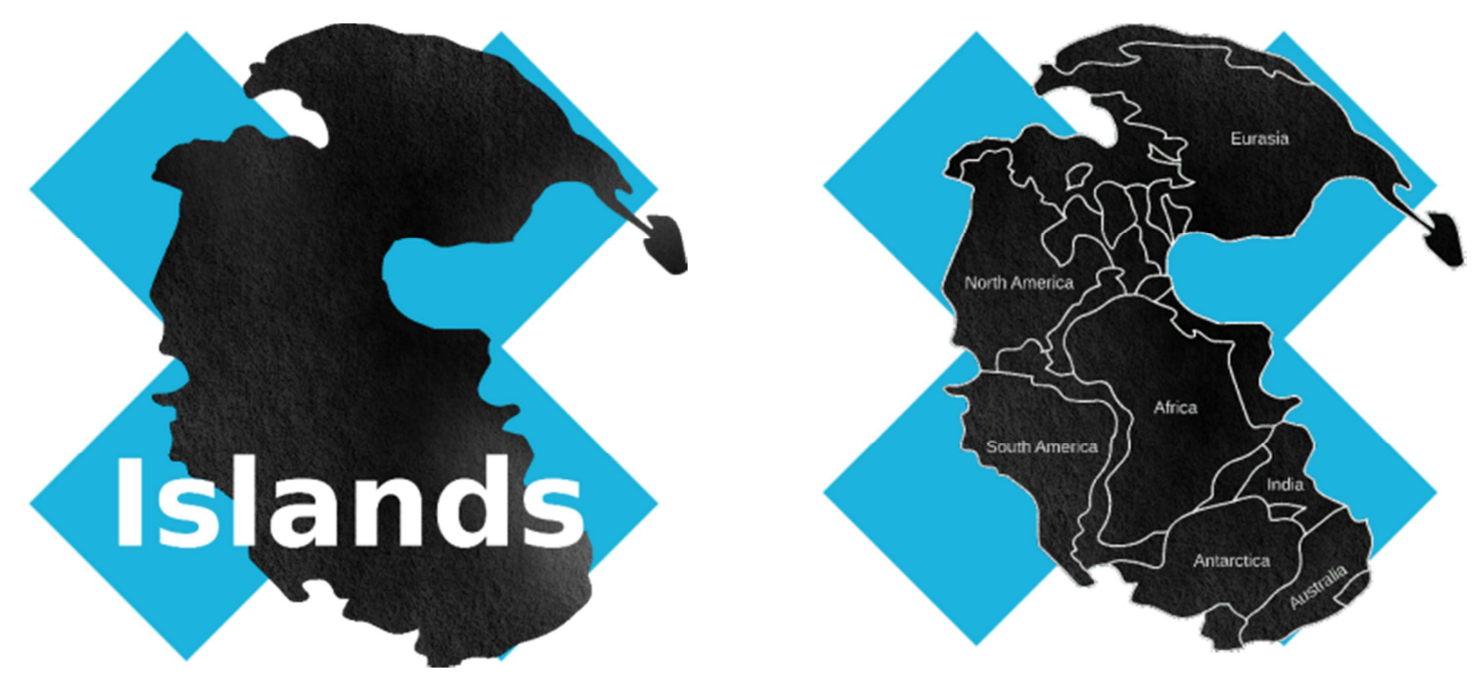

During the course, students were invited to explore what lessons can be learnt from the numerous islands around the world with regards to the concepts and perceptions related to islandness, how island perspectives can be used as study lenses, but also concretely how, for instance, remote islands met socio-economic challenges in the past (colonization, globalization), how they deal with present challenges and opportunities (cultural identity, food security) or prepare themselves for the future (climate change, energy security). The central idea of the IMPMW course, to view islands as study sites to facilitate knowledge development not only about islands but also about the world as a whole (cf. Royle, 2012; Warren et al., 
2015), is captured in the title of the course: "Islands: Models for our Planet: Metaphors for our World". To visualize this idea, a logo was developed with the contours of Pangea (Figure 1), the "super-island" that existed 225 million years ago when all continents were connected. This logo was used throughout the course in all course material and presentation slides.

'Interdisciplinary island studies' is a broad field encompassing a wide range of disciplines. Here, we use the term interdisciplinary studies to refer to the "process of answering a question, solving a problem, or addressing a topic that is too broad or complex to be dealt with adequately by a single discipline or profession [and] draws on disciplinary perspectives and integrates their insights through construction of a more comprehensive perspective" (Klein \& Newell, 1997, pp. 393-394). Because each island is complex and multifaceted, insights from multiple disciplines should be integrated to come to a fuller understanding (Newell, 2001). As a result of the enormous diversity of islands around the world, the field of island studies is diverse and heterogeneous. This is perfectly illustrated by the following quote from Stratford (2003, p. 495),

Islands (also islets, isles) - paradoxical spaces: absolute entities surrounded by water but not large enough to be a continent, territories, territorial; relational spaces archipelagos, (inter)dependent, identifiable; relative spaces - bounded but porous; isolated, connected, colonized, postcolonial; redolent of the performative imaginary; vulnerable to linguistic, cultural, environmental change; robust and able to absorb and modify; placed in regions, (part of) nation states and global life; paradisiacal, utopian and dystopian, tourist meccas, ecological refugia; frames within which interdisciplinary scholarship and dialogue can be constituted and deployed.

The keywords mentioned in the previous quote touch on topics from the social sciences, natural sciences, and humanities. In our view, an introductory course to interdisciplinary island studies would ideally encompass topics from all these intellectual domains (Figure 2).

Figure 2: Venn diagram of the position of interdisciplinary island studies at the interface of the social sciences, natural sciences, and humanities.

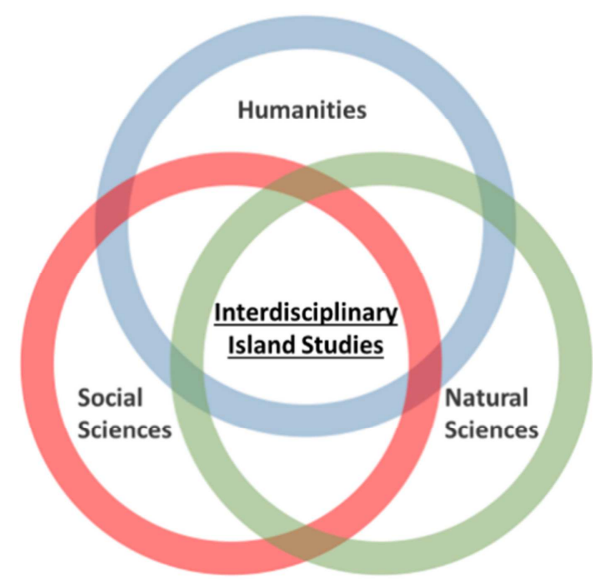

The main challenge of developing and teaching such a broad course is to introduce a wide range of topics in a coherent way. We sought to help students gain a deeper understanding of 
the underlying concepts of islands, instead of only presenting different topics separately. This is because, despite the great diversity and heterogeneity of islands, there are underlying structural themes or similarities across islands. To guide students throughout their learning process and to structure the content of the IMPMW course, a theoretical framework for interdisciplinary island studies was developed. In the following parts of the paper we will describe this framework and show how it was used throughout the course, followed by an elaboration on the course evaluation results.

\section{A framework for interdisciplinary island studies}

To illustrate the key concepts underlying the theoretical framework for interdisciplinary island studies, a visualization with the contours of Pangea was made (Figure 3). By describing the elements of the Pangea visualization in the following paragraphs, we will explain how different island perspectives are integrated in this framework.

Figure 3: Visualization of the concepts underlying the theoretical framework developed for the IMPMW course. (The different elements of the figure are explained in the text.)

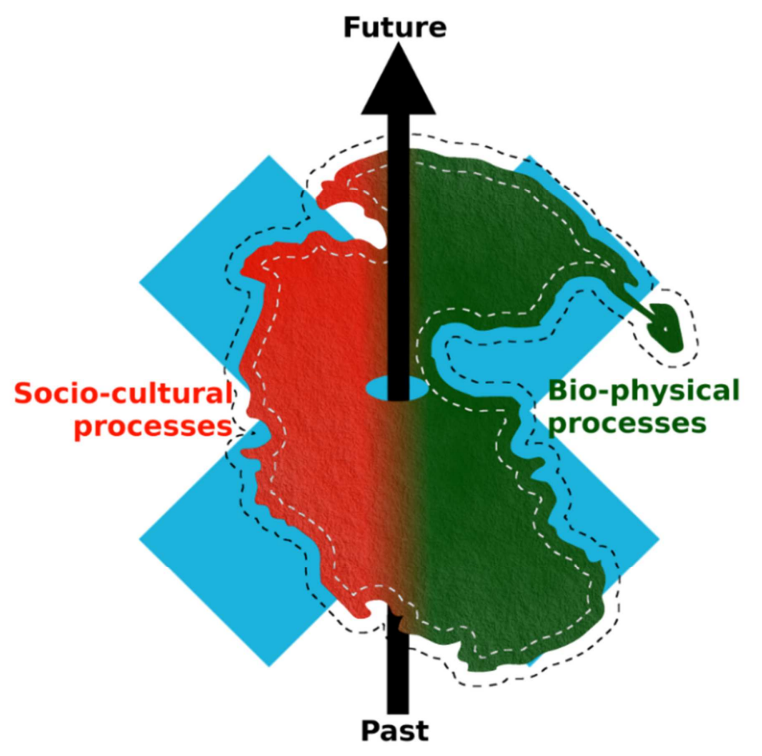

The Pangea outline of Figure 3 was used to symbolize that islands can facilitate the development of new insights about our world. That all continents were connected in the past highlights the fact that the degree to which islands are isolated depends on the time period under consideration. In the framework, spatial-temporal dynamics of island boundaries and isolation are symbolized by the dashed lines surrounding the island. In recent decades, the importance of physical boundaries may have decreased, as a result of processes related to globalization, giving rise to a "new Pangea" (Rosenzweig, 2001; Sax \& Gaines, 2003). However, globalization does not simply diminish or eliminate the relevance of physical boundaries; it creates new spatial relationships. For example, Sheppard (2002), points out that the way in which different entities (e.g. people, cities, nations) are related is not necessarily characterized by physical distance, but rather shaped by the intensity and nature of their interconnectedness. Positionality, the way in which such entities are positioned with respect to 
one another in space/time, changes as a result of globalization as well (Sheppard, 2002). The temporal dimension of the theoretical framework is represented in Figure 3 by the black arrow that runs from the past to the future. With this arrow we aim to visualize legacy effects, the "cumulative and evolving impacts of past interactions in coupled human- and natural systems on current and future conditions" (Liu et al., 2007, p. 643). On evolutionary timescales which can span thousands of years, islands change in size and even entire islands can disappear or emerge as a result of geological processes (Whittaker, Triantis, \& Ladle, 2008) and sea-level fluctuations (Fernández-Palacios et al., 2015). Also on shorter timescales, it is relevant to take into account historical processes that have shaped the way islands are today. For example, the colonial history of many islands has strong legacy effects on today's society and the environment. An interesting example is provided by Eriksen (1993) for the island Mauritius which was first settled by humans in 1638. During the centuries that followed, Mauritius went through several phases of demographic, sociocultural, and ecological changes that ultimately defined its current demography, and its successful socio-economy in spite of its currently degraded environment with more than $95 \%$ of its native forests being lost. The words of Percopo (2011, p. 93) poetically illustrate how islands change through time: "layers upon layers, histories after histories, wave upon wave". Islands can be thought of as nodes of connectivity, as places in time where people, goods, plant- and animal species, etc. come together. Rather than asking the question whether islands are dynamic or static, it should be asked at which rates an island is changing, at which timescales these changes are relevant, and how rates of change differ from desirable or natural background rates.

An increasing body of knowledge is being developed around the integrated analysis of social-ecological systems (Adger, 2000; Liu et al., 2007; Millennium Ecosystem Assessment, 2005). Islands in particular have a great potential to enhance the understanding of interactions between humans and the natural environment (Fitzpatrick \& Keegan, 2007). The red and green parts of Pangea (Figure 3) symbolize the socio-cultural and biological communities of islands. These communities are influenced by distant and internal socio-cultural and bio-physical processes. Of course, the division into a social, cultural, biological, and physical category could have been made differently; for clarification, we therefore briefly provide some examples for each of these categories. The social category comprises of, amongst other things, island politics, well-being, and island economics. Within the cultural category we include, amongst others, island art, island literature, tourism, and identity. The biological category consists of agriculture, nature conservation, and climate change, etc. Within the physical category we include for example island ontogeny and volcanism, but also energy production and waste management. It is clear that each of the given examples can sometimes be placed in more than one category, and that these may overlap: as does, for example, island tourism.

The blue cross underlying Pangea (Figure 3) aims to show that, even when considering the same physical island, different disciplinary perspectives exist. Depending on the disciplinary perspective of a researcher (the sides of the cross), a different view of the island is provided where only some facets of the island emerge (Newell, 2001). Which island boundaries are considered relevant (e.g. temporal, spatial, social, cultural, biological, physical) is dependent on the viewpoint of the researcher. Hay (2006) argues that, within the island studies community, there are different perspectives on islandness and size/scale. For example, should nissology be limited to scholars who are themselves islanders and/or limited to the study of small islands? Where the boundary is being drawn between large and small depends 


\section{S. J. Norder \& K. F. Rijsdijk}

on the focus of the study. This is not only a theoretical discussion but can also depend on practical considerations. As Meadows \& Wright (2009, p. 99) note,

It is a great art to remember that boundaries are of our own making, and that they can and should be reconsidered for each new discussion, problem, or purpose.

In a similar fashion, whether island boundaries are "hard" or "soft" (cf. Hay, 2006) also depends on the focus of the research. In the framework, the lines surrounding Pangea (Figure 3) are dashed to symbolize the selective permeability of island boundaries. Boundaries may be actual, analytical, socially constructed and natural at the same time, while these may not necessarily coincide fully with each other (Jentoft \& Chuenpagdee, 2009). Island boundaries seem obvious, as King (1993, p. 14) writes: "all other land divisions are more or less arbitrary". For many studies focused on islands however, the physical island as "a piece of land surrounded by water" is often not the actual unit of analysis. Divided islands are a good example of this: their jurisdictional borders do not align with the physical island boundaries, which might eventually lead to environmental and socioeconomic differences, as has been the case in Hispaniola (Diamond, 2005). Similarly, the positive or negative representation of islands (e.g. the promotion of island tourism, or portraying of islands in art and literature) can eventually shape island societies and environments as well. Royle (2014) shows how literary, artistic and cinematographic representations of islands shape the perception of islands. Fletcher (2011) proposes to adopt the concept of performative geographies for the study of islands as spaces of cultural production. Such an approach that attends to both 'real' and 'performative' aspects of islands is needed for a broad understanding of islands because, as Fletcher (2011, p. 26) notes, 'reality' and 'representation' are inseparable,

Those aspects of human culture which purport to describe social and material reality in fact create the vectors by which we navigate and comprehend that reality.

Acknowledging that island boundaries are dynamic, and are drawn differently by different researchers is an important starting point to find common ground and facilitate the interdisciplinary learning process. Within the course, islands are used literally as spatially explicit foci points, to study aspects of socioeconomic or ecological systems in a globalized world, as well as conceptually as a study lens for narrowing the research focus and reducing complexity. Emphasis is laid on deconstructing island concepts, such as isolation and physical boundaries as islands are connected to each other or hinterlands physically, economically and socially. Studying islands in an interdisciplinary team is about finding a balance between (actively) isolating an island (or island phenomenon) to be able to study it, and meanwhile doing justice to its complexity, diversity, and interconnectedness.

\section{Course structure}

The theoretical framework outlined in the previous paragraph was used to structure the IMPMW course. In developing the structure of a course, three aspects should be critically aligned (Biggs \& Tang, 2011): the intended learning goals, the teaching method, and the form of assessment. Below, each of these aspects is discussed in more detail. The intended learning 
goals of the IMPMW course are grouped into five overarching goals (Table 2) and are critically aligned with the interdisciplinary island studies framework (Figure 3).

\section{Table 2: Intended learning goals.}

After completion of this course, students should:

1) have gained an understanding of the role of islands in the world and critically reflect on current debates in the field of interdisciplinary island

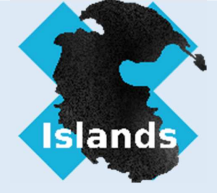
studies:

- Understand the role of islands in the development of existing and emerging scientific theories.

- Critically reflect on concepts such as islandness, isolation, boundaries, and identity.

- Critically reflect on the extent to which islands can be regarded as model and metaphor.

- Integrate insights from the social sciences, natural sciences, and humanities.

2) be able to recognize and describe which processes influence (or have influenced) the state of islands and their (biological and socio-cultural) communities:

- Recognize and describe how biological communities on islands are influenced by processes such as migration, adaptation and speciation, and extinction (amongst others).

- Recognize and describe how socio-cultural communities on islands are influenced by processes such as globalization, (de-) colonization, and migration (amongst others).

3) be able to understand how spatial and temporal dynamics shape islands and their (biological and socio-cultural) communities:

- Understand island dynamics at timescales of millions of years, to millennia, to centuries, and decades.

- Understand changes in the interactions among islands and between islands and continents through time.

4) be able to understand and evaluate the current state of islands and the future role of islands in the world:

- Understand and evaluate the most important challenges and opportunities islands and the rest of the world (will) face during the coming decades.

- Understand and evaluate what can be learnt from islands while facing current- and future global challenges and opportunities.

5) have (further) developed their academic skills:

- Apply the theory of the lectures and corresponding literature to a specific island.

- Analyze a specific case study and critically assess any lessons to be learnt from it.

- Write an individual paper that adheres to academic standards.

- Reflect on the work of peers and provide constructive feedback.

- Reflect on your own work and incorporate feedback from peers.

- Discuss your findings among peers and draw joint conclusions.

- Publish and present results of group discussions in coherent and appealing ways. 


\section{S. J. Norder \& K. F. Rijsdijk}

Regarding the teaching method, weekly meetings were organized to facilitate students in reaching the previously outlined learning goals. The module consisted of twelve weekly meetings (Table 3): ten interactive lectures, an exam and a symposium. Before the start of each lecture, Figure 3 was shown to indicate how the lecture connects with the preceding lectures. After the lecture, the topic of next week's lecture was briefly outlined to stimulate students to read the literature in advance. Before the start of the course, a document was sent to all participating guest lecturers to provide them with a clear overview of the course. In addition, one or more meetings were held with each guest lecturer to discuss the content of their lecture and how it relates to the preceding and subsequent lecture.

Table 3: General description of course plan, fine-tuned after the second year the course was organized (colour legend is beneath table).

\begin{tabular}{|c|c|c|}
\hline Wk & Content & eBook writing process. \\
\hline 1 & $\begin{array}{l}\text { - What is an island? } \\
\text { Diversity of islands: geological, } \\
\text { biological, cultural \& political diversity. } \\
\text { - Islands as models/ metaphors in social } \\
\text { sciences, natural sciences \& humanities. }\end{array}$ & $\begin{array}{l}\text { - Introduction by core-teachers and getting to } \\
\text { know the students (disciplinary background, } \\
\text { and previous experience with island studies). } \\
\text { - Overview of the course and the introduction of } \\
\text { the assignments (phases of writing the eBook). }\end{array}$ \\
\hline 2 & 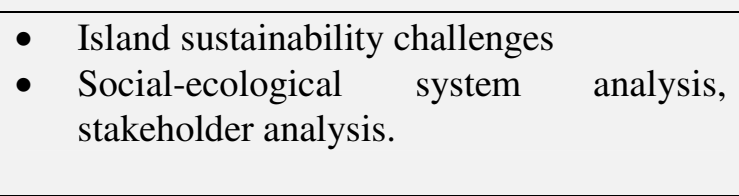 & $\begin{array}{l}\text { During the lecture: Students brainstorm in } \\
\text { small groups about an island sustainability case } \\
\text { study. Students are urged to involve both socio- } \\
\text { cultural as well as bio-physical aspects. }\end{array}$ \\
\hline 3 & $\begin{array}{l}\text { Evolution and biogeography } \\
\text { - Ecological boundaries, endemism, } \\
\text { dispersal, prehistoric human colonization. }\end{array}$ & $\begin{array}{l}\text { - Two days before the lecture: students submit } \\
\text { preparatory assignment that contains their } \\
\text { preference for a topic and an island and a } \\
\text { preliminary research question(s). } \\
\text { - At the end of the lecture: announce group } \\
\text { division and } 1^{\text {st }} \text { meeting with group members. }\end{array}$ \\
\hline 4 & $\begin{array}{ll}\text { - } & \text { Small economies: island challenges } \\
\text { - } & \text { Colonialism, in/dependence, migration. }\end{array}$ & - Working on individual paper \\
\hline 5 & $\begin{array}{l}\text { - Impacts of human colonization on island } \\
\text { biota. } \\
\text { - Island boundary dynamics, habitat } \\
\text { fragmentation, extinction. }\end{array}$ & - Working on individual paper \\
\hline 6 & $\begin{array}{lll}\text { - } & \text { Political geography } & \\
\text { - Legal boundaries, Small Island } \\
\text { Developing States, Subnational } & \text { Island } \\
\text { Jurisdictions. } & \end{array}$ & - Working on individual paper \\
\hline 7 & $\begin{array}{l}\text { - Representation of islands. } \\
\text { - Historical images, real versus imaginary } \\
\text { islands. }\end{array}$ & $\begin{array}{l}\text { - Working on individual paper } \\
\text { - } \quad \text { Reminder of approaching deadline. }\end{array}$ \\
\hline
\end{tabular}




\begin{tabular}{|c|c|c|}
\hline 8 & $\begin{array}{l}\text { - Human impact on island environments: } \\
\text { global lessons. } \\
\text { - Limited resources, population growth, } \\
\text { consumption. }\end{array}$ & $\begin{array}{l}\text { - Working on individual paper } \\
\text { - Two days after the lecture: deadline of } \\
\text { individual paper (first version). }\end{array}$ \\
\hline 9 & $\begin{array}{l}\text { - Socio-cultural and bio-physical } \\
\text { boundaries. } \\
\text { - Boundary dynamics, balancing isolation } \\
\text { and connectivity. }\end{array}$ & $\begin{array}{l}\text { - Before lecture: teachers and students read the } \\
\text { individual papers written by their group } \\
\text { members and provide feedback. } \\
\text { - After lecture: students start working on book } \\
\text { chapter as a group. Students share findings in } \\
\text { their group and explore options for integration. }\end{array}$ \\
\hline 10 & $\begin{array}{l}\text { - Shifting paradigms: island resilience and } \\
\text { innovation. } \\
\text { - Tourism imagology, complexity and } \\
\text { diversity. }\end{array}$ & - Working on book chapter within groups. \\
\hline 11 & - $\quad$ Multiple-choice exam & - Working on book chapter within groups. \\
\hline 12 & - Symposium & $\begin{array}{l}\text { - During symposium: students present book } \\
\text { chapters (about 15-20 min. per group) with } \\
\text { room for questions afterwards. } \\
\text { - Two days after symposium: book chapter } \\
\text { submission (including final versions of } \\
\text { individual papers). }\end{array}$ \\
\hline
\end{tabular}

Colour legend: grey = Introductory lectures, and lectures that aim to facilitate the process of writing the eBook; green $=$ emphasis mainly on natural sciences; red $=$ emphasis mainly on social sciences; blue $=$ emphasis mainly on humanities; light orange = sustainability topics at the interface of different disciplines.

The first lecture of the IMPMW course was a theoretical introduction to island studies as an academic discipline. The second lecture was more practical and aimed to facilitate students in working on the assignment. The following five lectures were guest lectures provided by island experts from different academic disciplines and institutions. We agreed to invite guest lectures from each of the three intellectual domains (social sciences, natural sciences, humanities) to keep the course as a whole appealing to students from different disciplinary backgrounds. Although not always practically feasible due to agenda constraints, the order of the lectures followed the vertical time axis, represented by the black arrow in Figure 3 (i.e. past - present future). Besides that, in the lectures earlier in the course there was more emphasis on the underlying concepts of the field of interdisciplinary island studies and on challenges faced by islands. Towards the end of the course, emphasis shifted to the (global) lessons that can be learnt from islands, and on innovative solutions implemented on islands. The order of the lectures and the eBook writing process are aligned, in the sense that the lectures become more integrative towards the end of the course when the group work becomes more intensive.

The assessment of the IMPMW course consisted of a multiple-choice exam and a written assignment (40\% and $60 \%$ of final grade respectively). A detailed description of the study load of each course element is found in the course manual (supplementary materials). The first form of assessment was a multiple-choice exam with 40 questions, four questions per lecture and corresponding literature. The exam was mainly used to assess those sub goals of learning goals 1-4 that were focused on "understanding" and "recognizing". The exam was added in the second year the course was organized, based on student evaluation results of the 


\section{S. J. Norder \& K. F. Rijsdijk}

first year. The exam was added to better assess the acquisition of factual knowledge from the lectures and corresponding literature; to stimulate a more critical reading of the literature; and to stimulate attentiveness during lectures. During the first year, attendance during the lectures was sometimes low, a known issue that exists in other elective evening courses.

The second form of assessment was a written assignment. This assignment consisted of an individual paper (50\% of final grade) grounded in a student's own discipline and a book chapter (10\% of final grade). For both the individual paper and the book chapter, a matrix was developed to translate the learning goals and their relative weights into concrete measures for assessment (the assessment criteria can be found in the assignment description in the supplementary materials). Since all participating students had finished at least the first year of their bachelor's degrees, they all had at least some basic skills in academic writing. However, because the standards used for academic writing differ amongst disciplines, an editable document was developed to provide a template for the structure and style (font type, referencing, etc.) of the individual paper and book chapter. The latter also facilitated the editing process of combining the book chapters into the eBook. The assignment description and templates for the individual paper and book chapter are shared in the supplementary materials. In the process of writing the individual paper and book chapter, students are guided through four different phases (Figure 4). Broadly speaking, individual students started by drawing on their disciplinary perspectives to subsequently integrate their insights through the construction of a more comprehensive perspective (Newell, 2001).

\section{Figure 4: Workflow for producing the eBook.}

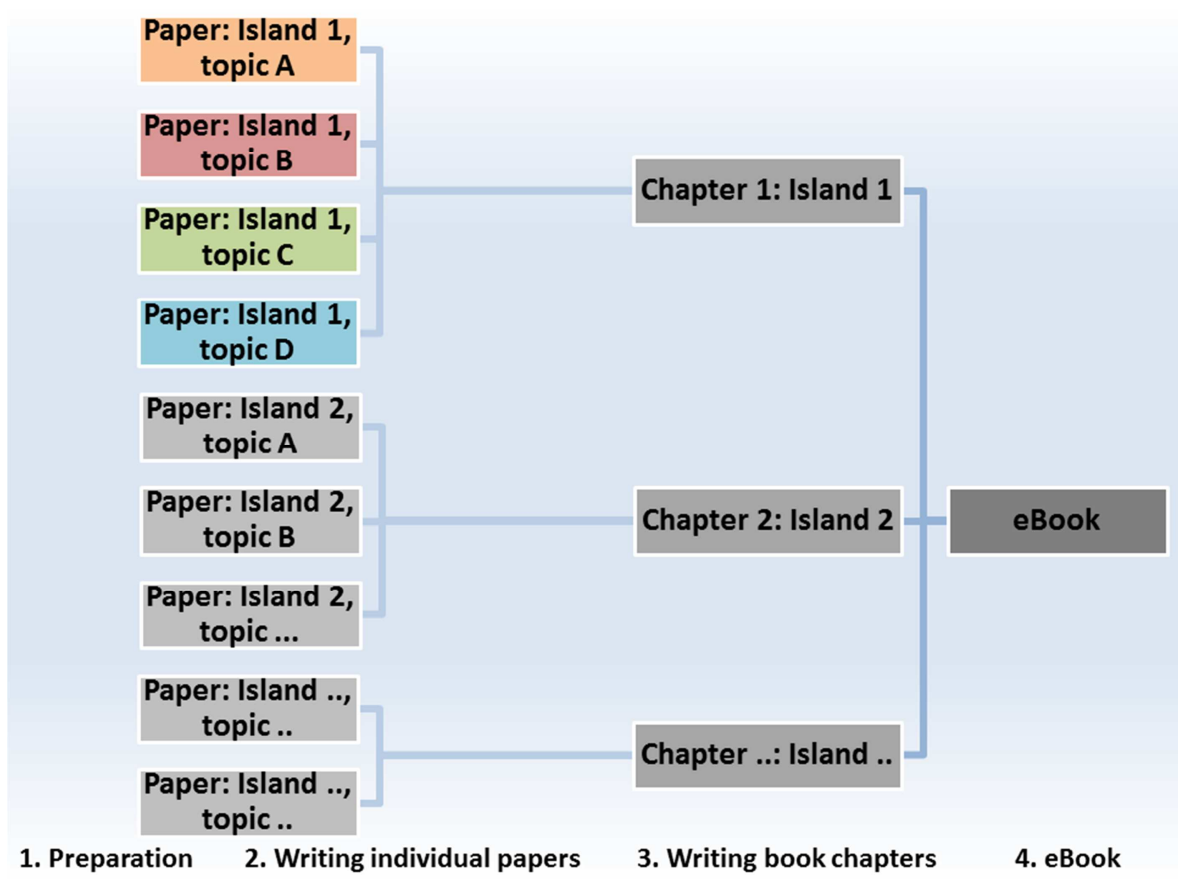

During the first phase (week 1-3), each student had to develop an initial research question, and decide on which island and topic to focus. Students were urged to choose a research question related to their own disciplinary training. Then, students that focused on the same island formed a group of ideally 4-6, with varied disciplinary backgrounds. Secondly (week 3-8), each student wrote an individual paper on a specific island and topic. At the end of this phase, 
students received feedback on their draft from teachers and group members. In the third phase (week 8-12), each group merged their individual papers into a book chapter and co-wrote its introduction and conclusion. Each group's chapter was presented during the symposium, after which students could finalize their chapter by incorporating feedback from the symposium.

When the course ended (after week 12), the core teachers of the module merged the book chapters into an eBook: this covered a wide range of topics and a broad geographical distribution of islands (supplementary materials). Islands and archipelagos covered in the book chapters include: Galápagos, Falklands, Bonaire, Hawai'i, Maldives, Iceland and Madagascar. Topics covered included: agriculture, biodiversity, well-being, politics, culture, economy, tourism, energy, water, waste and climate. For many students, working on the book chapter made them realize that, in dealing with an island, the topics tend to be intricately related.

\section{Course evaluation}

Overall, the course was very positively evaluated by students. In the $2^{\text {nd }}$ year, the course scored 8.1/10, 0.4 higher than the $1^{\text {st }}$ year. Nearly all aspects of the course were evaluated with a score between 3 to 4 out of 5: a good result. Those aspects of the course that were evaluated very positive $(\geq 4)$ or negative to moderate $(\leq 3)$ are shown in Table 4 . Results suggest that students felt they learned a lot, and that their learning process was facilitated by the structured course design, the lectures and feedback. However, the evaluation results also suggest that the course could have been more challenging. Inherent to a course that covers such a wide range of topics is that some aspects will be familiar to some students but less to others. A second area to improve dealt with such intellectual and cultural activities as film, music and literature, which were receiving scant attention. To improve the course balance in the future, more staff or guest lecturers with a humanities background should be involved.

Table 4: Average course evaluation results in the second year the course was organized.

\begin{tabular}{|l|c|}
\hline \multicolumn{1}{|c|}{ Course evaluation statement } & Score \\
\hline Positive aspects $(\geq \mathbf{4})$ & \\
\hline I learned a lot from this course. & 4 \\
\hline I learned fundamental principles and theories during this course. & 4 \\
\hline I acquired factual knowledge during this course. & 4.2 \\
\hline The course was clearly structured. & 4 \\
\hline The requirements set for the individual paper were clear. & 4 \\
\hline The lectures helped me to understand the subject matter. & 4.2 \\
\hline I received sufficient feedback on my work during the course as a whole. & 4 \\
\hline My supervisor provided good feedback on my individual paper. & 4 \\
\hline Negative aspects ( $\leq \mathbf{3})$ & 2.9 \\
\hline For me, the level of this course was too low (1)/too high (5). & 2.9 \\
\hline For me, the level of the lectures was too low (1)/too high (5). & 3 \\
\hline $\begin{array}{l}\text { I learned to understand / appreciate intellectual and cultural activities (music, film, literature) } \\
\text { during this course. }\end{array}$ & \\
\hline
\end{tabular}

Only course aspects evaluated very positive $(\geq 4)$ or negative to moderate $(\leq 3)$ are shown. All other evaluation questions were scored between 3 and 4 . 


\section{S. J. Norder \& K. F. Rijsdijk}

While the course was open to students from all disciplinary backgrounds, the percentage of students that enrolled in the course was unequally distributed over different intellectual domains: natural sciences $\left(65 \%\right.$ in $1^{\text {st }}$ year; $56.4 \%$ in $2^{\text {nd }}$ year), social sciences $(29 \% ; 33.3 \%)$, and humanities $(6 \% ; 10.3 \%)$. Despite our efforts, we didn't fully succeed in balancing lectures and literature from all intellectual domains (natural sciences, social sciences, humanities). Especially during the first year, the emphasis was more on the natural and social sciences. Integrating topics from the humanities during the second year was more successful; but this still requires attention to further strengthen the interdisciplinary character of the course.

Because this elective evening course was not a mandatory part of any curriculum, some students decided to quit halfway in order to prioritize their core curricular courses. This led to some practical issues because the teams who would work on a book chapter had already been formed. We solved this by merging some groups. For example, the groups focusing on Cyprus and Hispaniola were merged because they both studied divided islands. To ensure students were not disadvantaged by their group members, the weighting of the book chapter in the final grade was only $10 \%$. In addition, a low mark for the book chapter could be compensated for by a high mark on the individual paper. In case this course would be offered as part of a curriculum instead of an elective course, these measures would probably not be necessary.

The quality of individual papers and book chapters was evaluated with the previously mentioned assessment criteria (see supplementary materials), resulting in a grade between 1 and 10 . Overall, $89 \%$ of individual papers and $100 \%$ of book chapters were marked sufficient ( $\geq 5.5$ ). $58 \%$ of the students passed the exam at the first attempt. A low mark for the exam or book chapter could be compensated for by the individual paper; but, in order to pass the course, the individual paper had to suffice. Eventually, $89 \%$ of the students passed the course.

\section{Conclusion}

This essay serves two main goals: to describe the course structure of an introductory course in interdisciplinary island studies, and to present a theoretical framework for interdisciplinary island studies that was used to structure the course and guide students in their learning process. The central idea behind the course "Islands: Models for our Planet - Metaphors for our World" is that an interdisciplinary approach to studying islands can yield novel insights not only about islands, but might also provide lessons for the rest of the world. The developed theoretical framework proved useful to align the intended learning goals, the teaching method, and the form of assessment. The most important form of assessment was a written assignment during which students jointly worked on a book chapter for an eBook about islands. During this process, students with different disciplinary backgrounds studied one island from different angles. The integration of their individual findings in subsequent steps yielded a more comprehensive understanding of the island that was studied. This process helped students to appreciate the complexity and multiple facets of a single island. In addition, by attending the lectures and reading the literature, students gained a first overview of the inspiring and intriguing 'world of islands' (Baldacchino, 2007). The course was positively evaluated by students, but some aspects can be improved. Most importantly, the humanities component could be more strongly embedded and the course could be more challenging.

We hope that sharing our experiences in developing and teaching this course will facilitate teaching island studies elsewhere. Connecting teaching experiences from different island studies courses will further develop the interdisciplinary field of island studies. 


\section{Acknowledgements}

The authors thank the Institute for Interdisciplinary Studies for the opportunity to develop and teach the course described in this paper, which benefited from the feedback and conversations with participating students. We acknowledge the valuable discussions and input from (in alphabetical order): Aki Ackerman, Godfrey Baldacchino, Arie Boomert, Linda de Greef, José María Fernández-Palacíos, Steije Hofhuis, Henry Hooghiemstra, Machiel Keestra, Joris Klingen, Dorien van Kranenburg, Vanessa Lambrecht, Henk van der Liet, Steph Menken, Myrte Mijnders, Cynthia Nagel, Mirko van Pampus, Ryan Peterson, Bert de Reuver, Jessica Rodermans, Jaap Rothuizen, Stephen Royle, Gunter Senft, Coyan Tromp, Julia Wright, Jeroen van der Zalm, and an anonymous reviewer. SN received funding for part of the work from Portuguese National Funds, through FCT: Fundação para a Ciência e a Tecnologia, within the project UID/BIA/00329/2013 and the research Fellowship PD/BD/114380/2016.

\section{Supplementary materials}

Table 5: Overview of supplementary materials.

\begin{tabular}{|l|}
\hline \multicolumn{1}{|c|}{ File name and description } \\
\hline Course Manual.doc \\
\hline Assignment individual paper and book chapter.doc (This file includes assessment criteria.) \\
\hline Layout for individual paper.doc \\
\hline Layout for book chapter.doc \\
\hline Lecture X - presentation format.pdf \\
\hline Models for our Planet-Metaphors for our World - eBook 2016.pdf \\
\hline Facebook page (https://www.facebook.com/groups/1126907893989705/) \\
\hline Promotional movie (https://youtu.be/nVPhjmT7M4) \\
\hline
\end{tabular}

Note: All supplementary materials can be downloaded from the Island Studies Journal website for this issue: http://www.islandstudies.ca/node/479

\section{References}

Adger, W. N. (2000). Social and ecological resilience: are they related? Progress in Human Geography, 24(3), 347-364.

Baldacchino, G. (Ed.) (2007). A world of islands: An island studies reader. Luqa, Malta \& Charlottetown, Canada: Agenda Academic \& Institute of Island Studies.

Biggs, J., \& Tang, C. (2011). Teaching for quality learning at university. Berkshire: The Society for Research into Higher Education \& Open University Press.

Diamond, J. (2005). Collapse: How societies choose to fail or succeed. London: Allen Lane.

Eriksen, T. H. (1993). In which sense do cultural islands exist? Social Anthropology, 1(1B), 133-147.

Fernández-Palacios, J. M., Rijsdijk, K. F., Norder, S. J., Otto, R., de Nascimento, L., Fernández-Lugo, S., ... Whittaker, R. J. (2015). Towards a glacial-sensitive model of island biogeography. Global Ecology and Biogeography, 25(7), 817-830. 


\section{S. J. Norder \& K. F. Rijsdijk}

Fitzpatrick, S. M., \& Keegan, W. F. (2007). Human impacts and adaptations in the Caribbean islands: an historical ecology approach. Earth and Environmental Science Transactions of the Royal Society of Edinburgh, 98(1), 29-45.

Fletcher, L. (2011). "...some distance to go": a critical survey of Island Studies. New Literatures Review, (47-48), 17-34.

Hay, P. (2006). A phenomenology of islands. Island Studies Journal, 1(1), 19-42.

Jentoft, S., \& Chuenpagdee, R. (2009). Fisheries and coastal governance as a wicked problem. Marine Policy, 33(4), 553-560.

King, R. (1993). The geographical fascination of islands. In D.G. Lockhart, D. DrakakisSmith, \& J.A. Schembri (Eds.), The development process in small island states (pp. 1337). London: Routledge.

Klein, J. T., \& Newell, W. (1997). Advancing interdisciplinary studies. In J. Gaff \& J. Ratcliff (Eds.), Handbook of the undergraduate curriculum. San Francisco CA: Jossey-Bass.

Liu, J., Dietz, T., Carpenter, S. R., Folke, C., Alberti, M., Charles, L., ... Redman, C. L. (2007). Coupled human and natural systems. AMBIO: A Journal of the Human Environment, 36(8), 639-649.

Meadows, D., \& Wright, D. (2009). Thinking in systems: A primer. London: Earthscan.

Millennium Ecosystem Assessment. (2005). Ecosystems and human well-being: synthesis. Washington DC: Island Press.

Newell, W. H. (2001). A theory of interdisciplinary studies. Issues in Integrative Studies, 25(19), 1-25.

Percopo, L. (2011). On the trail of the post-colonial: transcultural spaces, cosmopolitanism, and the islands of the Mediterranean. New Literatures Review, (47-48), 91-110.

Rosenzweig, M. L. (2001). The four questions: What does the introduction of exotic species do to diversity? Evolutionary Ecology Research, 3(3), 361-367.

Royle, S. A. (2012). Lessons from islands, or islands as miners' canaries? In G. Baldacchino (Ed.), Extreme heritage management: the practices and policies of densely populated islands. (pp. 246-259). New York: Berghahn Books.

Royle, S. A. (2014). Islands: Nature and Culture. London: Reaktion Books.

Sax, D. F., \& Gaines, S. D. (2003). Species diversity: from global decreases to local increases. Trends in Ecology \& Evolution, 18(11), 561-566.

Sheppard, E. (2002). The spaces and times of globalization: place, scale, networks and positionality. Economic Geography, 78(3), 307-330.

Stratford, E. (2003). Flows and boundaries: small island discourses and the challenge of sustainability, community and local environments. Local Environment, 8(5), 495-499.

Stuart, K. (2010). Teaching island studies: on whose terms. Island Studies Journal, 5(2), 251-260.

Sunderlin, D., \& Xu, L. (2008). An island studies course at a liberal arts institution: pedagogy from a natural history perspective. Island Studies Journal, 3(2), 199-210.

Warren, B. H., Simberloff, D., Ricklefs, R. E., Aguilée, R., Condamine, F. L., Gravel, D., ... Thébaud, C. (2015). Islands as model systems in ecology and evolution: Prospects fifty years after MacArthur-Wilson. Ecology Letters, 18(2), 200-217.

Whittaker, R. J., Triantis, K., \& Ladle, R. J. (2008). A general dynamic theory of oceanic island biogeography. Journal of Biogeography, 35(6), 977-994. 